SIR,-Your leader writer (24 April, p. 183), states without quotation of his authority that "tuberculous infection of the genital tract usually arises in the prostate and seminal vesicles."

If not positively untrue, this assumption is at least highly questionable. Some 20 years ago I demonstrated, on the basis of the study of 55 patients, ${ }^{1}$ that the commonest route of infection of the genital tract is the urinary tract, beginning in the kidney. I argued that "tuberculous epididymitis is a sign of renal tuberculosis" and that "every case should be submitted to careful and if necesary repeated urinary investigation." I believe this is generally accepted today. The exclusion of "acid-fast bacilli in the urine" is only one step in such an investigation.

In the antepenultimate paragraph we read "diversion is usually by uretero-colic anastomosis". I think many, if not most urologists would question this bald statement. There are many alternative procedures of which uretero-ileostomy ${ }^{2-4}$ may be the least acceptable but is unquestionably the safest in the long term. - I am, etc.,

Hoylake

Charles Wells

1 Wells, C. A., British fournal of Urology, 1938, 2 Annis, D., Proceedings of the Royal Society of Medicine, 1952, 45, 483

3 Bricker, E. M., Surgery, 1952, 32, 372 . 1082.

SIR,-Your leading article on this subject (24 April, p. 183) calls for comments.

You say that "in $10 \%$ of patients it is not the urinary tract but the epididymis which causes symptoms." In Britain's largest former colony, Nigeria, the opposite prevails, the genital tract being almos exclusively affected and urinary tuberculosis being of great rarity. So much is this so that one doubted the usefulness and soundness of the concept of genitourinary tuberculosis as an entity. ${ }^{1}$ In view of the large numbers of overseas students and doctors who seek their training in Britain the time has now come for writers to make it clear of which geographical disease pattern they speak and to cease generalizing Otherwise we shall be accused of medical parochialism by those who know something about the wider world.

The second comment concerns your ex cathedra statement that "dead or caseous tissue will protect viable organisms from drugs diffusing in from healthy tissues". I wonder what proof your leader writer has for this? It is now clear that, at any rate in spinal tuberculosis treated by antituberculous drugs alone spinal abscesses disappear, caseous material and bony debris is absorbed, and bony or fibrous union takes place. ${ }^{2}$ - I am, etc.,

Peter Konstam

Orkney Isles

1 Konstam, P. G., American fournal of Surgery, Konstam, P. G., and Blesovsky, A., British fournal of Surgery, 1962, 50, 26.

SIR,-In your leading article on genitourinary tuberculosis (24 April, p. 183) you state "Though PAS is still somewhat expen- sive, its general freedom from side effects gives it undoubted advantages." This is, of course, quite untrue of PAS; it is relatively inexpensive and carries a high incidence of most unpleasant side effects. In the context of the paragraph concerned, the substitution of "ethambutol" for "PAS" in the abovequoted sentence would make factual sense. Perhaps this was intended.

The enthusiasm shown, in the same paragraph, for rifampicin should be reserved for daily treatment in patients with healthy livers; hepatotoxicity is not uncommon. ${ }^{1}$ Furthermore, twice - weekly rifampicin therapy, in 1,200 mg doses, produces a high incidence of unacceptable side effects. One, immune thrombocytopenia, is potentially extremely serious. ${ }^{3}$ Clearly, further investigation into the toxicity of this drug is required before its true position can be assessed.-I am, etc.,

Royal Postgraduate Medical School

Peter Stradling

London $\mathbb{W} .12$

1 Lesobre, R., Ruffino, J., Teyssier, L., Achard, F., and Brefort, G., Revue de la Tuberculose et de Pneumologie, 1969, 33, 393.

Lees, A. W., Asgher, B., Hasham, M.A., and Sinha, B. N., British
Chest, 1970, 64, 90 .

3 Blajchman, M. A., Lowry, R. C., Pettit, J. E. and Stradlin

** We much regret an error in the leading article, in which it was stated that PAS is still somewhat expensive and that its general freedom from side effects gives it undoubted advantages. These remarks were intended to apply to rifampicin.-ED., B.M.f.

\section{Liver Damage and Methotrexate}

SIR,-It is by now quite well known that the toxicity of methotrexate is not proportional to the dose but rather to the time for which a given plasma level is maintained. The longer this time is, the greater the toxicity. Low doses given daily are nearly always more toxic than high doses given intermittently. Thus $100 \mathrm{mg}$ methotrexate given as ten consecutive daily doses of $10 \mathrm{mg}$ each would produce profound toxicity, possibly even death, whereas it is possible to give 20,000 $\mathrm{mg}$ intravenously as a 24-hour infusion without any overt toxicity at all. ${ }^{2}$ It is therefore not surprising that Dr. M. G. Dahl and his colleagues (20 March, p. 625) found that continuous low dose therapy in psoriatic patients produced more texicity than doses given intermittently.

At this institute nearly 50 infusions varying from 400 to $9,000 \mathrm{mg}$ have been given and we have never seen any hepatic fibrosis in those patients resistant to methotrexate who subsequently died from their disease. Furthermore, no mention is made of renal function in his paper. This is important since in patients with impaired renal function even single doses given intermittently are retained for a sufficient time to cause toxicity. This toxicity can be abolished by giving the patient folinic acid 24 hours after the dose of methotrexate. In addition if liver damage parallels damage to the bone marow, which seems kinetically likely, then the timing of the liver biopsy in relation to the last dose of methotrexate may be important. Thus four days after an infusion of $5,000 \mathrm{mg}$ methotrexate a bone marrow biopsy shows mild depression, whereas it is quite normal 10 days after the drug has been given. In short, the toxicity of methotrexate cannot be logically discussed unless renal function and the time for which a given plasma level is maintained are stated.-I am, etc.

L. A. Price

Chester Beatty Rescarch Institute, London S.W.3

1 Bergsagel, D., Modern Medicine of Canada, 1969, 24, No. 1, p. 19.
Goldie, J., Price, L. A., and Harrap, K. R. 1971, in press.

SIR,-We would like to report observations which differ from those recently reported by Dr. M. G. C. Dahl and others (20 March, p. 625), and Dr. J. J. R. Almeyda and others (17 April, p. 167).

In Sheffield methotrexate has been given to psoriatics in interrupted daily oral dosage for up to $\mathbf{7 8}$ months and abnormal liver biopsies were found in 15 out of 21 of these patients. Three were frankly cirrhotic; four showed mild to moderate hepatic fibrosis, and eight had varying degrees of fatty change alone. Two of the cirrhotics drank excessive amounts of alcohol, the third admitted to drinking alcohol only rarely and gave no history of infectious hepatitis. The liver damage did not correlate with either duration of therapy or cumulative dosage $(0 \cdot 1-4 \cdot 125 \mathrm{~g})$ of methotrexate.

Seven biopsies taken from patients about to begin methotrexate were all abnormal. Six showed fatty change and one fibrosis. As Dr. M. G. C. Dahl and colleagues pointed out in their paper, abnormal hepatic histology in long-standing psoriasis has been noted previously. ${ }^{2}$ It is evident that the part played by methotrexate in producing liver damage will not be clarified until the results of prospective studies are available.-We are, etc.,

H. M. PALMER

I. B. SNEDDON

Hallamshire Hospital,

Shefficld

1 Huriez, C., Desmons, F., Benoit, M., and Martin, P., British fournal of Dermatology, 1957, 69, 237

Berge, G., Lundquist, A., Rorsman, H., and Akerman, M., British fournal of Dermatology, 1970 82, 250 .

\section{Obstetric Appointments and the Abortion Act}

SIR,-Now that legalized abortion is being discussed in New Zealand, I would be grateful if readers would let me know if reports we hear about British hospital practice are factual or not. We are told that candidates for obstetrical and gynaecological posts are first asked if they will co-operate in the abortion programme of that hospital, and their selection depends on the answer to this question.

I would be interested to hear if this is actually true, and if the inquiry is simply a verbal one or an official one approved by the hospital management committee. The implications for future candidates for the M.R.C.O.G. are obvious.-I am, etc.,

H. P. DUNN 